\title{
Comparative evaluation of cardiovascular effects showed best results of ropivacaine front prilocaine on extractions simple in the jaw
}

\author{
Igor Mariotto Beneti ${ }^{1,2,3 *}$, Jessica Lemos Gulinelli ${ }^{4}$, Daniela Ponzoni ${ }^{3}$, Daniela Atili Brandini ${ }^{3}$, Alessandra Marcondes Aranega ${ }^{3}$, Idelmo \\ Rangel Garcia Júnior ${ }^{3}$ and Idiberto José Zotarelli Filho
}

${ }^{1}$ Unorp - University Center North Paulista - São José do Rio Preto, SP, Brazil

${ }^{2}$ Unipos - Post graduate and continuing education, São José do Rio Preto, SP, Brazil

${ }^{3}$ Faculty of Dentistry - Foa - Unesp, Araçatuba, SP, Brazil

${ }^{4}$ Universidade Sagrado Coração- Bauru-SP-Brazil

\begin{abstract}
The ropivacaine local anesthetic long-term, has been widely used in clinical medicine, though few studies have been conducted using the anesthetic for dental procedures. Thus, it is objective of this study comparing the effects of ropivacaine and prilocaine in the cardiovascular system when used in simple extractions procedures after the blockade in anesthesia infiltrating terminals jaw. To this end, 14 healthy patients (Class 1 - anesthetic risk rating recommended by the American Society of Anesthesiology) were selected and received anesthetic infiltration of $3.6 \mathrm{~mL}$ of $0.75 \%$ ropivacaine and $3.6 \mathrm{ml}$ of prilocaine $3 \%$ for extraction of third molars jaw. It was administered only one type of anesthetic in each region (right and left) of the patient. Data were collected regarding the vital signs (pulse, blood pressure and oximetry) in the first consultation, before anesthesia, 5, 10, 15, 20 and 30 minutes after anesthetic infiltration. The data were subjected to statistical analysis of variance, adopting the significance level of $5 \%$. The use of $0.75 \%$ ropivacaine solution no significant effect on systolic and diastolic blood pressure, heart rate and oxygen saturation; compared to $3 \%$ prilocaine solution. There was no vasoconstrictor effect site with the ropivacaine solution was used. Within the limitations of this study it is concluded that bupivacaine $0.75 \%$ compared to prilocaine $3 \%$ showed no statistically significant cardiovascular changes and marked intrinsic vasoconstrictor effects were not observed in this study.
\end{abstract}

\section{Introduction}

Local anesthesia is pain control method most commonly used in dentistry. In Brazil, it is used about 250 million of anesthetic cartridges per year [1]. This huge volume of local anesthetic used by dentists and produced anesthetic quality have encouraged the search for new agents that cause minimal side effects.

Currently numerous anesthetic solutions have been researched and marketed, promising the dentist a lasting effectiveness and less discomfort to the patient during and after the operation [2]. However, the ideal local anesthetic that should have reversible action, not to be annoying tissues, providing low degree of systemic toxicity, to start fast action, appropriate duration, enough power for a full anesthesia, not highly concentrated, have sufficient penetration, being barely able to trigger allergic reactions, be stable in solution, undergoes rapid biotransformation in the body and be sterile [3], unfortunately still exists in the market.

Ropivacaine was first used in 1992 and released for clinical use in medicine in 1996 [4-6] is structurally similar to bupivacaine, but prepared with a pure s-enantiomer, while bupivacaine is a mixture racêmica [7-9]. Ropivacaine may be helpful as a local anesthetic for mandibular nerve block in dentistry, and is favorable in reducing postoperative pain present for a long time in the pulp and soft tissue $[10,11]$.

According to the toxicity tests "in vitro" and animal studies, ropivacaine showed smaller effect on the central nervous system (CNS) and reduced cardiotoxicity compared to bupivacaína [7,12-19]. This fact can be explained by the low affinity ropivacaine by heart cells. Moreover, its plasma half-life is shorter, ensuring a faster elimination, less potential for accumulation in tissues and higher margin segurança [20].

Numerous studies have shown that dermal ropivacaine have vasoconstrictive properties that can influence the duration of the anesthetic effect of infiltrative injection [21-24], and adding the vasoconstrictor anesthetic ropivacaine does not improve efficiency or life compared to isolated use of the drug [25].

However, Kennedy et al. (2001) [18] showed that injection of ropivacaine with epinephrine in maxillary anterior human has the potential to replace bupivacaine with epinephrine in dental clinical practice to present lower cardiac toxicity and potential SNC. The vasoconstrictor is used mainly to slow the absorption local anesthetics; improving its action and reducing the occurrence of undesirable effects [26,27]. Few studies have been conducted to evaluate the effects of $0.75 \%$ ropivacaine in dentistry, in this way. It seems to be useful to study

Correspondence to: Igor Mariotto Beneti, Faculty of Dentistry - Foa - Unesp, Araçatuba-SP, Brazil, Tel: +55-17-98112-9215; E-mail: igor.beneti@globo.com

Received: June 08, 2015; Accepted: July 29, 2015; Published: August 03, 2015 
the action of these cardiovascular parameters in patients undergoing dental surgery, comparing it to a standard anesthetic [18].

The aim of this study is to evaluate the effects of ropivacaine $0.75 \%$ and prilocaine $3 \%$ felypressin on systolic and diastolic blood pressure, heart rate and oxygen saturation, as well as the clinical observation of the vasoconstrictor effect during dental surgery.

\section{Study design}

After approval by the Ethics Committee on Human Research of FOA - UNESP (embodied Opinion No. 526/05), this study was conducted with patients in the Department of Oral and Maxillofacial Surgery. Each participant signed the free and informed consent prior to the same. As inclusion criteria of patients in the study were considered: healthy patients who were not using drugs and without serious background on your medical history, carriers of third molars (teeth 18:28) erupted and orthodontic indication of extraction.

The survey data was conducted on a sample of 14 patients during surgery of extraction. The teeth to be extracted (a total of 28 teeth) were divided into two groups: Group I: infiltrative terminal anesthesia with ropivacaine $0.75 \%$ (Naropin ${ }^{\circ}$-Astrazeneca). This anesthetic showed up wrapped bottles. The solution was then aspirated with a sterile disposable plastic syringes and needles and placed inside sterile plastic carpules (similar to group II) which were sealed with the rubber plunger. Group II: terminal infiltrative anesthesia with prilocaine $3 \%$ to 0.03 felypressin ui (Citocaine $e^{\bullet}$ DFL).

All patients received anesthesia in both groups, in different sessions, one on the right for extraction of the tooth 18 and the other on the left to tooth extraction [28]. The selection of patients for the study and groups of procedures performed was defined by draw, and when the operator received anesthesia the anesthetic cartridge mounted without identifying the group to which he belonged.

All anesthetic and surgical procedures were performed by a single operator. The distribution of anesthetic cartridges and data collection were performed by a single researcher.

Anesthetic techniques infiltrative terminal followed the guidance of Bennett. Previously was applied to the mucosa topical anesthetic (EMLA) [28]. Each procedure was performed using two anesthetic cartridges (3, $6 \mathrm{ml}$ solution). Each anesthetic cartridge was injected with the aid of sterile carpule syringe with short needles ( $30 \mathrm{~g})$ disposable over 2 minutes.

In all procedures were collected data regarding vital signs such as pulse and blood pressure through blood pressure device not invasiva(Dixtal/2710 CITY) and oximetry (Oximeter Dixtal/2455, CITY).

The measurement times are adapted from Meechan [11,17] protocol: First consultation; Immediately before anesthetic infiltration (time 0); Five minutes after anesthetic infiltration; Ten minutes after anesthetic infiltration; Fifteen minutes after anesthetic infiltration; Twenty minutes after anesthetic infiltration; Thirty minutes after anesthetic infiltration.

During the second surgical session, the patient was asked about the difference of burning/anesthetic discomfort between the current anesthetic and anesthetic applied during the first surgery.

Onset of anesthesia was measured at times of 5,10 and 12 minutes. Through scalpel blades inserts No. 15 on the buccal and palatal teeth that were extracted. The extraction was performed by simple extraction method, having begun after 12 minutes of anesthesia.

Data were analyzed using statistical software (SPSS version 16.0, SPSS, Chicago), with statistical significance of 0.05 . To compare the differences between groups I and II was used ANOVA and Student $t$ test for continuous variables samples.

\section{Results}

The study included 14 participants with an average age of 21.93 (years) and standard deviation of 3.26 (years). An analysis of variance was performed to compare the impact of prilocaine $3 \%$ and $0.75 \%$ ropivacaine in pulse oximetry, SBP and DBP of patients during the third molar surgery. There was no statistically significant difference between the groups oximetry $(\mathrm{p}=0.055)$, wrist $(\mathrm{p}=0.177)$, the $\mathrm{SBP}(\mathrm{p}=0.134)$ and DBP $(0.150)$, and eta effect was small for all (eta squared $=0.02 ; 0.01$, 0.012 and 0.011 , respectively) (Table 1) (Figure 1).

Post-hoc comparisons using the Tukey HDS test indicated that the mean score of 5 to pulse in time was significantly different ( $\mathrm{p} \leq$ 0.001 ) between groups (prilocaine, $\mathrm{M}=83.2, \mathrm{SD}=18.9$ and ropivacaine $\mathrm{M}=73.8$, SD 14.8) (Table 1). It was found that the group with prilocaine there was a sharp drop on the pulse of patients compared to initial time,

Table 1. Prilocaine comparison with ropivacaine regarding oximetry, pulse, systolic blood pressure and diastolic blood pressure.

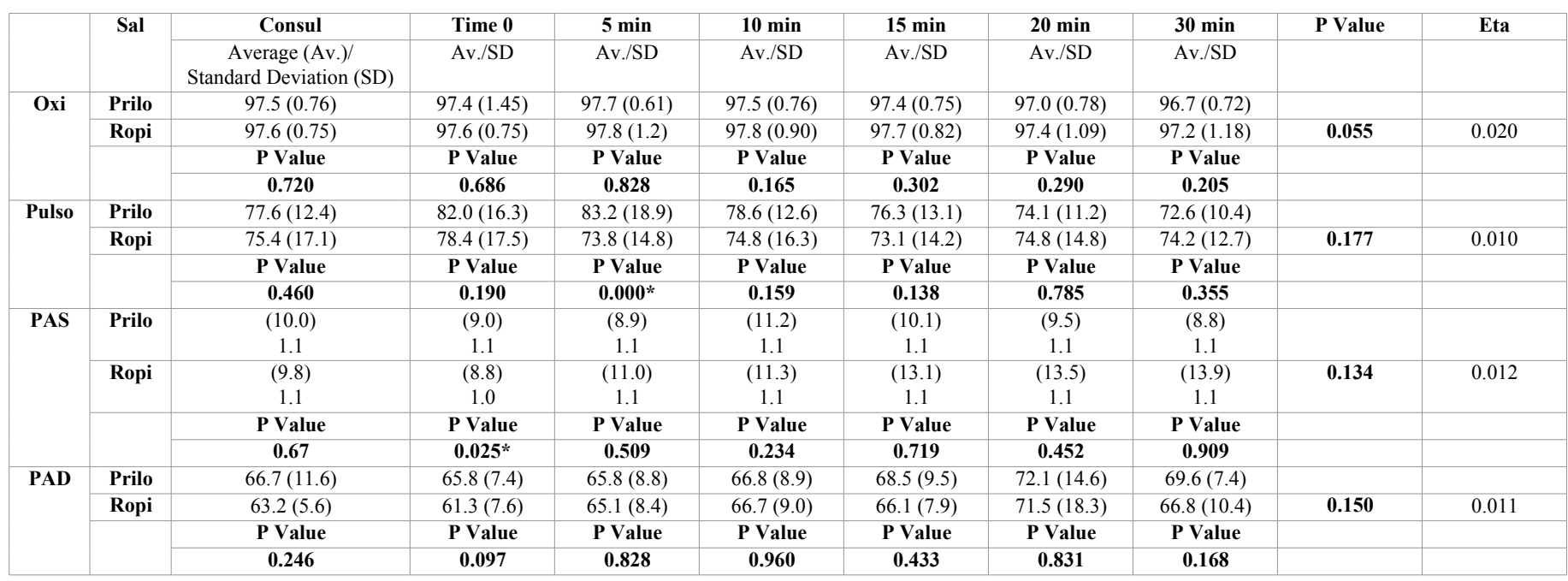




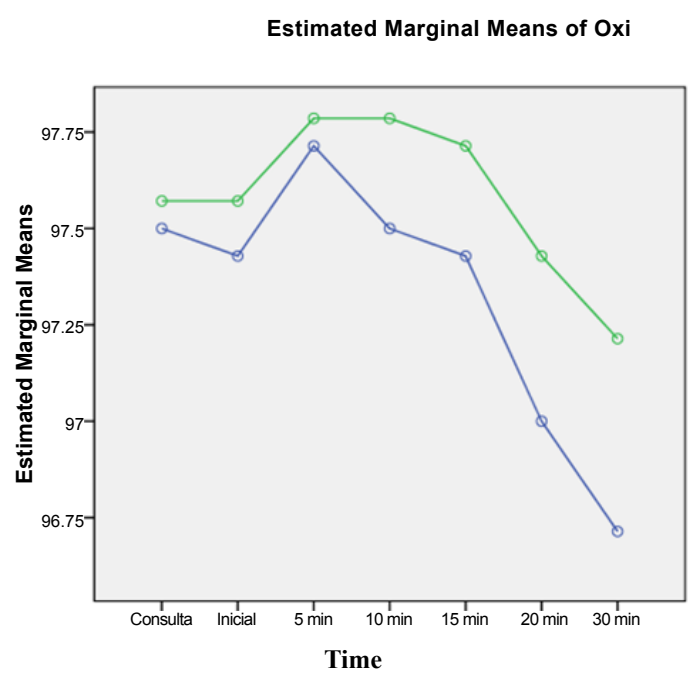

Figure 1. Oximetry variation in the periods studied.

Estimated Marginal Means of Pulso

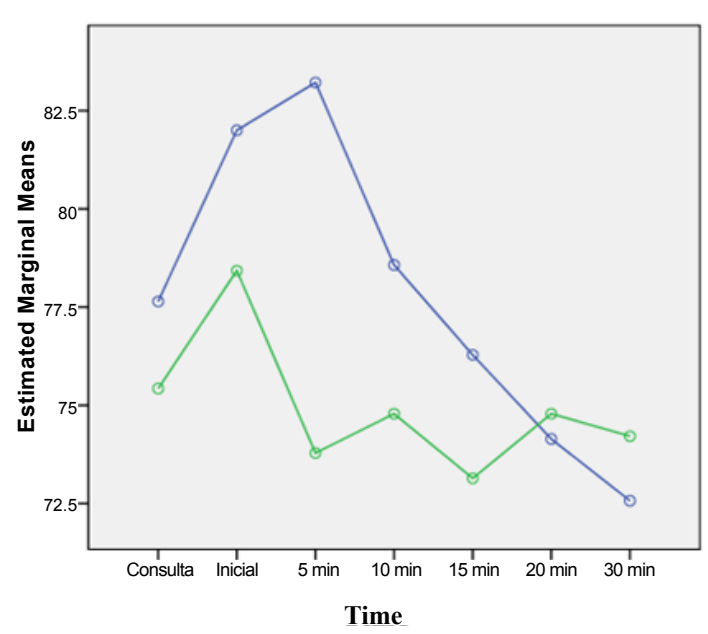

Figure 2. Pulse variation the periods studied.

however on the pulse of ropivacaine group showed a steady increase (Figure 2).

Figure 3 shows the SBP between the groups. The statistically significant difference in the initial time cannot be exploited by the action of the anesthetics however ropivacaine group increased PAS rapidly, from time 0 to 5 , being similar to the other group. The same development can be seen with PAD in Figure 4.

The Blazing evaluated anesthetic showed that $100 \%$ of patients reported greater discomfort during infiltration of ropivacaine. The anesthetic latency measured at the time of five minutes showed that all patients had infiltration with prilocaine in that period showed no signs of pain. Now ropivacaine, all patients evaluated in the 5-minute period had pain complaints. In the 10-minute period, the patients who received infiltration with prilocaine remained painless and patients operated with ropivacaine only $28.57 \%$ had no pain complaints. In the period of twelve (12) minutes both anesthetics were effective for all patients.

\section{Discussion}

Ropivacaine appeared on the market as a long lasting anesthetic with low cardiotoxicity, neurotoxicity and vasoconstrictor effect intrínsico [11]. Moreover, it has selectivity of action for the sensory block compared to the block motor [29].

This paper chose the human model for extraction of third molars by fidelity of obtaining data on routine in the clinical practice. Once the patients had selected the members 18 and 28 for extraction, and these procedures were performed in different sessions, no interference effect of a solution on the other.

The prilocaine anesthetic solution with felypressin was used as a control group for failing to act on alpha and beta adrenergic receptors, eliminating the possibility of interference on the parameters evaluated in this study. Moreover, it is one of the solutions most commonly used in dentistry. Other anesthetics without vasoconstrictor for its rapid absorption and vasodilatory effect, which makes clinical work, were not used. The changes in the parameters of vital signs were of little

Estimated Marginal Means of PAS

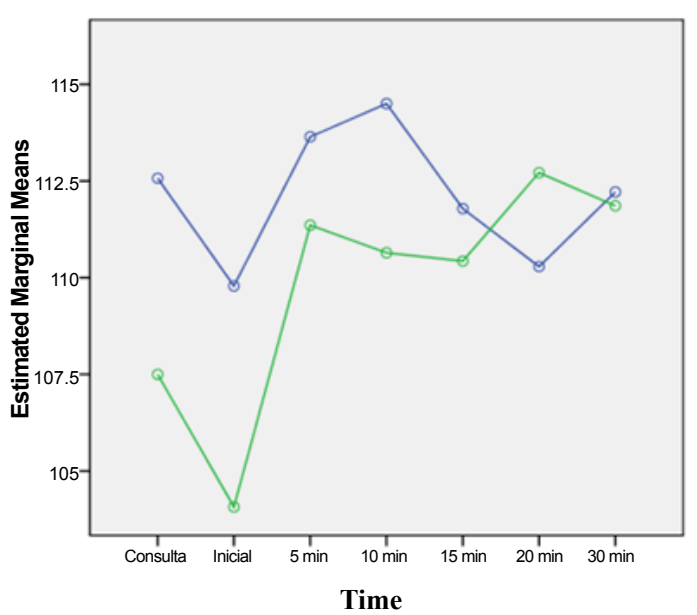

Anesthetics - prilo

Figure 3. Graphic variation of systolic blood pressure in the periods studied.

Estimated Marginal Means of PAD

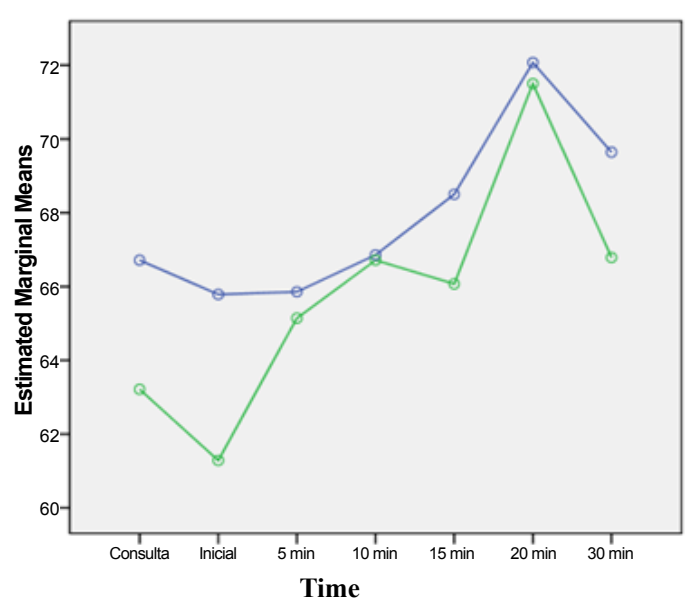

Anesthetics - prilo

Figure 4. Graphic variation of diastolic blood pressure in the periods studied. 
significance and not statistically significant for the groups. This shows that ropivacaine can be used in dental surgical procedures safety where there is a need of a local anesthetic with a prolonged time of action.

The parameters that were analyzed are subject to changes induced by operative and release of endogenous adrenaline stimuli, raising the heart rate and blood pressure, considering that the patients did not receive any sedation for the procedure. This can be observed separately in the variation of values in the pulse group prilocaine, which cannot be assigned to the local anesthetic.

The choice of anesthetic can influence the discomfort during infiltration. Especially anesthetics associated to vasoconstrictors or high concentrações [17]. Although, ropivacaine has $\mathrm{pK}$ value of 8.1, it has not been associated with epinephrine in our study. The same complaints presented Blazing larger than prilocaine. This can be explained by concentration of $0.75 \%$ ropivacaine.

In this study the rapid onset of action ropivacaine described in the literature was not observed [30]. Unlike El-Sharrawy et al. (2006) which claim that the onset of action is 1 to 2.2 minutes; in this study there was a minimum latency of 10 to 12 minutes, which can be explained by the pK value of 8.1 presented by the anesthetic salt studied in this work.

But the intrinsic vasoconstrictor effect of ropivacaine, reported in the literature, could not be observed clinically during exodontias [31]. The drape of the sites where it was used ropivacaine visually presented a more profuse bleeding than anesthetized sites with prilocaine with felypressin.

It is extremely important that vasoconstrictors are present in anesthetic solutions for use in Odontologia [17]. Among the properties of local anesthetics is their vasodilatory capacity, a factor that leads to membership of a vasoconstrictor in the anesthetic solution in order to facilitate dental procedures. The vasoconstrictors reduce blood flow at the injection site and thus increase the residence time of anesthetic solution into the tissue, and reduce the risk of toxicity of the solutions and to promoting a surgical field exangue [17].

It is suggested that ropivacaine, if used in dental local anesthetic for surgical purposes, is associated with vasoconstrictors in order to obtain a bloodless operative field.

\section{Conclusion}

Within the limitations of this study, it was concluded that ropivacaine compared to prilocaine not statistically significant cardiovascular changes and the deep intrinsic vasoconstrictor effects were not observed in this study.

\section{Conflict of interests}

The authors declare that they have no competing interests.

\section{Acknowledgement}

The work was financially supported by the Unipos of Sao Jose do Rio Preto-Brazil. We appreciate the support of pharmacy and Base Hospital of Sao Jose do Rio Preto-Brazil, also Duke University (Durham, NC, USA) in the field of research and statistical studies.

\section{References}

1. Ramacciato JR, Tófoli GR, Groppo FC, Volpato MC, Ranali J (2003) Os avanços da anestesia local em odontologia. Rev Assoc Paul Cir Dent 57: 455-9.

2. Mees ML, Portela IC, Carlini JL (1997) Uso dos anestésicos locais em odontologia. Rev Bras Odontol 54: 273-276.
3. Bennett CR. analgesia regional. In: monhein, 1.m., bennett, c.r. anestesia local e controle da dor na prática dentária. 7.ed. Rio de Janeiro: Guanabara Koogan, 1986: 33-42.

4. Gatt S, Crooke D, Lockley S, Anderson AJ, Armstrong P, Alley L (1996) A doubleblind, randomized, parallel investigation into neurobehavioural status and outcome of infants born to mothers receiving epidural ropivacaine $0.25 \%$ and bupivacaine $0.25 \%$ for analgesia in labour. Anesthesia and Intensive Care 24: 108-109.

5. Markham A, Faulds D (1996) Ropivacaine. A review of its pharmacology and therapeutic use in regional anaesthesia. Drugs 52: 429-449. [Crossref]

6. Krzemi Å ski TF, Gilowski L, Wiench R, PÅ,ocica I, Kondzielnik P, et al. (2011) Comparison of ropivacaine and articaine with epinephrine for infiltration anaesthesia in dentistry - a randomized study. Int Endod J 44: 746-751. [Crossref]

7. McCrae AF, Jozwiak H, McClure JH (1995) Comparison of ropivacaine and bupivacaine in extradural analgesia for the relief of pain in labour. Br J Anaesth 74 : 261-265. [Crossref]

8. Porter JM, Markos F, Snow HM, Shorten GD (2000) Effects of respiratory and metabolic $\mathrm{pH}$ changes and hypoxia on ropivacaine-induced cardiotoxicity in dogs. $\mathrm{Br}$ $J$ Anaesth 84: 92-94. [Crossref]

9. Knudsen K, Beckman Suurküla M, Blomberg S, Sjövall J, Edvardsson N (1997) Central nervous and cardiovascular effects of i.v. infusions of ropivacaine, bupivacaine and placebo in volunteers. Br J Anaesth 78: 507-514. [Crossref]

10. Ernberg M, Kopp S (2002) Ropivacaine for dental anesthesia: a dose-finding study. $J$ Oral Maxillofac Surg 60: 1004-1010. [Crossref]

11. Brkovic BM, Zlatkovic M, Jovanovic D, Stojic D (2010) Maxillary infiltration anaesthesia by ropivacaine for upper third molar surgery. Int J Oral Maxillofac Surg 39: 36-41. [Crossref]

12. Feldman HS (1994) Toxicity of local anaesthetic agents. New york: Raven press 107 133.

13. Danielsson BR, Danielson MK, Böö EL, Arvidsson T, Halldin MM (1997) Toxicity of bupivacaine and ropivacaine in relation to free plasma concentrations in pregnant rats: a comparative study. Pharmacol Toxicol 81: 90-96. [Crossref]

14. Sztark F, Ouhabi R, Dabadie P, Mazat JP (1997) Effects of the local anesthetic bupivacaine on mitochondrial energy metabolism: change from uncoupling to decoupling depending on the respiration state. Biochem Mol Biol Int 43: 997-1003. [Crossref]

15. Capogna G, Celleno D, Fusco P, Lyons G, Columb M (1999) Relative potencies of bupivacaine and ropivacaine for analgesia in labour. Br J Anaesth 82: 371-373. [Crossref]

16. Magalhães E, Govêia CS, Oliveira KB (2004) Racemic bupivacaine, levobupi vacaine and ropivacaine in regional anesthesia for ophthalmology -- a comparative study. Rev Assoc Med Bras 50: 195-198. [Crossref]

17. Meechan JG1 (2002) A comparison of ropivacaine and lidocaine with epinephrine for intraligamentary anesthesia. Oral Surg Oral Med Oral Pathol Oral Radiol Endod 93 469-473. [Crossref]

18. Kennedy M, Reader A, Beck M, Weaver J (2001) Anesthetic efficacy of ropivacaine in maxillary anterior infiltration. Oral Surg Oral Med Oral Pathol Oral Radiol Endod 91: 406-412. [Crossref]

19. Reiz S, Häggmark S, Johansson G, Nath S (1989) Cardiotoxicity of ropivacaine--a new amide local anaesthetic agent. Acta Anaesthesiol Scand 33: 93-98. [Crossref]

20. Wang RD, Dangler LA, Greengrass RA (2001) Update on ropivacaine. Expert Opin Pharmacother 2: 2051-2063. [Crossref]

21. Kopacz DJ, Carpenter RL, Mackey DC (1989) Effect of ropivacaine on cutaneous capillary blood flow in pigs. Anesthesiology 71: 69-74. [Crossref]

22. Dahl JB, Simonsen L, Mogensen T, Henriksen JH, Kehlet H (1990) The effect of 0.5\% ropivacaine on epidural blood flow. Acta Anaesthesiol Scand 34: 308-310. [Crossref]

23. Cederholm I, Evers H, Löfström JB (1991) Effect of intradermal injection of saline or a local anaesthetic agent on skin blood flow--a methodological study in man. Acta Anaesthesiol Scand 35: 208-215. [Crossref]

24. Cederholm I, Akerman B, Evers H (1994) Local analgesic and vascular effects of intradermal ropivacaine and bupivacaine in various concentrations with and without addition of adrenaline in man. Acta Anaesthesiol Scand 38: 322-327. [Crossref]

25. Hickey R, Candido KD, Ramamurthy S, Winnie AP, Blanchard J, et al. (1990) Brachial plexus block with a new local anaesthetic: 0.5 per cent ropivacaine. Can J Anaesth 37 : 732-738. [Crossref] 
Beneti IM (2015) Comparative evaluation of cardiovascular effects showed best results of ropivacaine front prilocaine on extractions simple in the jaw

26. Louro RS, Moreira LM, Miranda MS, Medeiros PJ (2001) Estudo comparativo do uso do cloridrato de prilocaína a 3\% com felipressina a 0.03 UI e do cloridrato de lidocaína a $2 \%$ com adrenalina a 1:100000 em pacientes hipertensos. $R B O 58: 228-231$.

27. de Oliveira MA, Tortamano N, Armonia PL, Rocha RG (1986) Comparative study of the effects of lidocaine with noradrenaline and prilocaine with felypressin on the cardiovascular system of dogs, according to variations in dosage, time and route of administration. Rev Fac Odontol Sao Paulo 24: 75-92. [Crossref]

28. Bennett CR (1986) Anestésicos locais e soluções anestésicas. In: monhein, 1.m., bennett, c.r. anestesia local e controle da dor na prática dentária. (7 ed) Rio de Janeiro: Guanabara Koogan 75-98.
29. Connolly C, Coventry DM, Wildsmith JA (2001) Double-blind comparison of

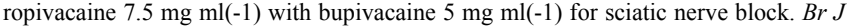
Anaesth 86: 674-677. [Crossref]

30. El-Sharrawy E, Yagiela JA (2006) Anesthetic efficacy of different ropivacaine concentrations for inferior alveolar nerve block. Anesth Prog 53: 3-7. [Crossref]

31. Akerman B, Hellberg IB, Trossvik C (1988) Primary evaluation of the local anaesthetic properties of the amino amide agent ropivacaine (LEA 103). Acta Anaesthesiol Scand 32: 571-578. [Crossref]

Copyright: (2015 Manzini R. This is an open-access article distributed under the terms of the Creative Commons Attribution License, which permits unrestricted use, distribution, and reproduction in any medium, provided the original author and source are credited. 